\title{
Gold-functionalized magnetic nanoparticles restrict growth of Pseudomonas aeruginosa
}

This article was published in the following Dove Press journal:

International Journal of Nanomedicine

8 May 2014

Number of times this article has been viewed

\author{
Katarzyna Niemirowicz ${ }^{1,2}$ \\ Izabela Swiecicka ${ }^{3}$ \\ Agnieszka Z Wilczewska ${ }^{4}$ \\ Iwona Misztalewska ${ }^{4}$ \\ Beata Kalska-Szostko ${ }^{4}$ \\ Kamil Bienias ${ }^{2}$ \\ Robert Bucki 1,5,6 \\ Halina $\mathrm{Car}^{2}$ \\ 'Department of Microbiological \\ and Nanobiomedical Engineering, \\ ${ }^{2}$ Department of Experimental \\ Pharmacology, Medical University \\ of Bialystok, ${ }^{3}$ Department of \\ Microbiology, ${ }^{4}$ Institute of Chemistry, \\ University of Bialystok, Bialystok, \\ ${ }^{5}$ Faculty of Health Sciences, Jan \\ Kochanowski University, Kielce, \\ Poland; ${ }^{6}$ Institute for Medicine \\ and Engineering, University of \\ Pennsylvania, Philadelphia, PA, USA
}

\begin{abstract}
Superparamagnetic iron oxide nanoparticles (SPIONs) and their derivatives (aminosilane and gold-coated) have been widely investigated in numerous medical applications, including their potential to act as antibacterial drug carriers that may penetrate into bacteria cells and biofilm mass. Pseudomonas aeruginosa is a frequent cause of infection in hospitalized patients, and significant numbers of currently isolated clinical strains are resistant to standard antibiotic therapy. Here we describe the impact of three types of SPIONs on the growth of $P$. aeruginosa during long-term bacterial culture. Their size, structure, and physicochemical properties were determined using transmission electron microscopy, X-ray diffraction analysis, and Fourier transform infrared spectroscopy. We observed significant inhibition of $P$. aeruginosa growth in bacterial cultures continued over 96 hours in the presence of gold-functionalized nanoparticles $\left(\mathrm{Fe}_{3} \mathrm{O}_{4} @ \mathrm{Au}\right)$. At the 48-hour time point, growth of $P$. aeruginosa, as assessed by the number of colonies grown from treated samples, showed the highest inhibition (decreased by $40 \%$ ). These data provide strong evidence that $\mathrm{Fe}_{3} \mathrm{O}_{4} @ \mathrm{Au}$ can dramatically reduce growth of $P$. aeruginosa and provide a platform for further study of the antibacterial activity of this nanomaterial.
\end{abstract}

Keywords: antibacterial activity, Pseudomonas aeruginosa, superparamagnetic nanoparticles, iron oxides, gold-coated nanoparticles

\section{Introduction}

Pseudomonas aeruginosa is an important opportunistic pathogen involved in a number of infections, especially in patients with compromised host defense mechanisms and adults with cystic fibrosis, in whom it is responsible for about $70 \%$ of chronic lung infections. ${ }^{1-4} P$. aeruginosa can also colonize a number of medical devices, increasing the spread of bacteria in health care institutions..$^{5-7}$ Pseudomonas infections, like those caused by many other bacteria found in hospitals, are becoming more difficult to treat. Firstly, the pattern of biofilm growth with this bacteria has a key role in the development of chronic infection. Secondly, P. aeruginosa is known to have significant protective mechanisms against antibiotic activity, which significantly decrease drug penetration and thus increase antibiotic resistance.

Nanotechnology has paved the way for development of new methods to treat and prevent bacterial diseases. ${ }^{8-11}$ There is now a wealth of data suggesting that certain properties of magnetic nanoparticles, such as resistance to biodegradation processes, surface activity, and ability to penetrate bacterial cell membranes, are useful for development of new antibacterial therapies. Many studies have shown divergent effects of nanoparticles against bacteria which could be linked with dose, nature of
Correspondence: Halina Car Department of Experimental Pharmacology, Medical University of Bialystok, 37 Szpitalna, I5-295 Bialystok, Poland

Tel +48 857485554

Email zfarmdosw@umb.edu.pl 
the nanomaterial, external factors, and bacterial strain. ${ }^{12-15}$ A very promising future lies ahead for the application of functionalized superparamagnetic iron oxide nanoparticles (SPIONs) and their potential for magnetic targeting to bacterial cells and biofilm mass. It was recently shown that SPIONs functionalized with carboxylate groups could disrupt biofilms and retard the growth of Staphylococcus aureus by over $35 \%$ after 24 hours of incubation. ${ }^{10}$ Further, ciprofloxacin loaded onto magnetic nanocomposites of poly(vinyl alcohol)-gpoly(methyl methacrylate) have been reported to kill bacteria efficiently when released under magnetic control. ${ }^{16}$

Recent data have shown that magnetic nanoparticles can penetrate biofilm. Inactivation of pathogens in the presence of an external magnetic field is also possible after induction of hyperthermia. ${ }^{17,18}$ Metal oxide nanoparticles, such as silver, gold, selenium, and ferrum, are also under investigation for their inherent antimicrobial properties. ${ }^{9}$ It is also important to determine how nanoparticles affect host cells. An absence of toxicity is required for use of nanoparticles in future medical treatment. In this work, we assessed the effect of three types of iron oxide nanoparticles on the growth of $P$. aeruginosa over a 96-hour incubation period. We observed a marked decrease in $P$. aeruginosa density in continuously growing inocula, particularly at the 48-hour time point in the presence of gold-functionalized nanoparticles $\left(\mathrm{Fe}_{3} \mathrm{O}_{4} @ \mathrm{Au}\right)$. We also found that $\mathrm{Fe}_{3} \mathrm{O}_{4} @ \mathrm{Au}$ had a different effect in a human skin fibroblast cell line from that seen in P. aeruginosa. A possible mechanism for the interaction between $\mathrm{Fe}_{3} \mathrm{O}_{4} @ \mathrm{Au}$ and $P$. aeruginosa is discussed.

\section{Materials and methods}

\section{Synthesis of magnetic nanoparticles}

SPIONs were synthesized by a modified Massart method, based on chemical coprecipitation of $\mathrm{Fe}^{2+}$ and $\mathrm{Fe}^{3+}$ ions in an alkaline solution. ${ }^{19}$ In this procedure, $2.15 \mathrm{~g}$ of $\mathrm{FeCl}_{2} \cdot 4 \mathrm{H}_{2} \mathrm{O}$ and $5.8 \mathrm{~g}$ of $\mathrm{FeCl}_{3}$ were dissolved separately in $200 \mathrm{~mL}$ of deionized water. The two solutions were then mixed and heated to $75^{\circ} \mathrm{C} ; 7.5 \mathrm{~mL}$ of ammonium hydroxide $(25 \%)$ was then added to the solution, followed by further heating for 30 minutes. $\mathrm{Fe}_{3} \mathrm{O}_{4} @ \mathrm{Au}$ were obtained by a modification of the K-gold method, ${ }^{20}$ whereby 0.6 g of uncoated nanoparticles were dispersed in $20 \mathrm{~mL}$ of deionized water, with subsequent addition of $45 \mathrm{mmol} \mathrm{NaOH}, 7.85 \mathrm{mmol} \mathrm{HAuCl}_{4}, 6.6 \mathrm{mmol}$ $\mathrm{NaBH}_{4}$, and $20 \mathrm{mmol}$ citric acid. Next, the nanoparticles were washed three times with water and ethanol. Aminosilanefunctionalized nanoparticles $\left(\mathrm{Fe}_{3} \mathrm{O}_{4} @ \mathrm{NH}_{2}\right)$ were synthesized using a one-step polycondensation method. One gram of uncoated nanoparticles were redispersed in ethanol under argon gas protection. The solution of nanoparticles was then mixed with $2 \mathrm{~mL}$ of ammonium hydroxide and $0.5 \mathrm{~mL}$ of 3-aminopropyl trimethoxysilane in $2 \mathrm{~L}$ of ethanol under a flow of argon gas (5.0 Air Liquide, Houston, TX, USA). After 5 hours, the prepared $\mathrm{Fe}_{3} \mathrm{O}_{4} @ \mathrm{NH}_{2}$ were washed three times with ethanol. Following synthesis, all the nanoparticle samples were placed in an oven at $60^{\circ} \mathrm{C}$ and dried into powder over 12 hours.

\section{Characterization of magnetic nanoparticles}

Fourier transform infrared spectra were recorded using a Nicolet ${ }^{\circledR} 6700$ ATR spectrometer (Thermo Fisher Scientific, Waltham, MA, USA) at room temperature. The average particle sizes, distribution and morphology of each nanoparticle was examined using a Tecnai ${ }^{\mathrm{TM}}$ transmission electron microscope (TEM/EDAX, G2 X-TWIN, FEI, Hillsboro, OR, USA) operated at a voltage of $200 \mathrm{kV}$. Energy-dispersive X-ray analysis was done using an EDAX detector installed on the same TEM instrument. Crystalline analysis were done using a SuperNova ${ }^{\mathrm{TM}} \mathrm{X}$-ray diffractometer (Agilent Technologies, Santa Barbara, CA, USA) equipped with a microfocus Mo source $\left(\mathrm{k}_{\alpha} 0.7136 \AA\right)$. For the measurements, small amounts of the powdered samples were placed on the pin holder and centered in a four-circle goniometer.

\section{Antimicrobial testing}

P. aeruginosa obtained from the Polish Collection of Microorganisms (Institute of Immunology and Experimental Therapy, Wrocław, Poland) was grown overnight at $37^{\circ} \mathrm{C}$ in Luria-Bertani broth (Oxoid, Basingstoke, UK) with shaking at $250 \mathrm{rpm}$. The bacteria were sedimented by centrifuging at 5,000 $\mathrm{g}$ for 10 minutes at $4^{\circ} \mathrm{C}$, and resuspended in Brain Heart Infusion (BHI) medium (Oxoid) to an $\mathrm{OD}_{600}$ of 0.5 , which corresponds to $10^{9}$ cells. Each type of nanoparticle dissolved in BHI was added in a proportion of $1: 1$. The final concentration of nanoparticles was $2.5 \mathrm{mg} / \mathrm{mL}$. The bacterial cultures were grown with the nanoparticles for 96 hours with shaking at $250 \mathrm{rpm}$. Bacteria growing in BHI without nanoparticles served as a control. The control was diluted 1:1 by BHI not containing nanoparticles. Every 24 hours, $500 \mu \mathrm{L}$ of the culture were taken to examine the number of living cells by plate count.

\section{Statistical analysis}

The experiments were conducted in triplicate and repeated three times. Differences in the collected data were determined 
using the one-tailed Student's $t$-test. Statistical analysis was performed using Statistica version 10 (StataCorp LP, College Station, TX, USA).

\section{Results and discussion}

A comparison of the Fourier transform infrared spectra for solid samples of aminosilane and gold-functionalized nanoparticles and the uncoated controls is shown in Figure 1. TEM-based techniques were used to evaluate the size and the shape of the nanoparticles. The TEM images were measured at high magnification. The particles were found to be spherical, with an estimated average size of $9 \mathrm{~nm}, 10 \mathrm{~nm}$, and $13 \mathrm{~nm}$ for $\mathrm{Fe}_{3} \mathrm{O}_{4}, \mathrm{Fe}_{3} \mathrm{O}_{4} @ \mathrm{NH}_{2}$, and $\mathrm{Fe}_{3} \mathrm{O}_{4} @ \mathrm{Au}$, respectively. The TEM images and histograms showing the size distribution of the magnetic nanoparticles are presented in Figure 2. The silica and gold coating around the magnetic core can be observed on the TEM images as obtained from 3-aminopropyltrimethoxsilane and gold chlorideused during synthesis. The ratios of elements in the modified $\mathrm{Fe}_{3} \mathrm{O}_{4}$ nanoparticles were characterized by energy-dispersive X-ray and TEM analysis, and are shown for $\mathrm{Fe}_{3} \mathrm{O}_{4} @ \mathrm{NH}_{2}$ and $\mathrm{Fe}_{3} \mathrm{O}_{4} @ \mathrm{Au}$ in Tables 1 and 2, respectively. Energy-dispersive X-ray spectra collected from the samples imaged by TEM clearly show the presence of a silica signal from $\mathrm{Fe}_{3} \mathrm{O}_{4} @ \mathrm{NH}_{2}$ (Figure 3A) and a gold signal from $\mathrm{Fe}_{3} \mathrm{O}_{4} @ \mathrm{Au}$ (Figure 3B). Peaks at $8 \mathrm{keV}$ and $8.9 \mathrm{keV}$ are attributable to the copper in the copper grid. $\mathrm{X}$-ray diffractograms of the respective samples are shown in Figure 4. A similar basic set of diffraction patterns can be seen in each sample. The diffractograms typical signals (220) (311) (400) (422) (333) (440) (531) (731) appear, confirming adequate crystallinity of the unmodified nanoparticles. ${ }^{21}$ In addition, weak signals typical for hematite (012) can be observed in the nanoparticles coated with an aminosilane shell. ${ }^{22}$ For particles covered with gold, the crystalline structure of metallic gold can be observed. ${ }^{23}$ The coherent diffraction zone was calculated from the width of the X-ray diffraction peaks using the Debye-Scherrer approximation, ${ }^{24}$ and was found to be $10 \pm 2 \mathrm{~nm}, 11 \pm 2 \mathrm{~nm}$, and $15 \pm 2 \mathrm{~nm}$ for $\mathrm{Fe}_{3} \mathrm{O}_{4}, \mathrm{Fe}_{3} \mathrm{O}_{4} @ \mathrm{NH}_{2}$, and $\mathrm{Fe}_{3} \mathrm{O}_{4} @ \mathrm{Au}$, respectively, which is in agreement with data obtained from TEM

$$
\mathrm{D}=\frac{0,9 \cdot \lambda}{\mathrm{B}_{1 / 2} \cdot \cos \theta}
$$

where D is the grain size $(\AA), \lambda$ is the wavelength $(0.70931 \AA$ for the Mo source), $B_{1 / 2}$ is the full width at half maximum intensity of the peak (rad), and $\theta$ is the diffraction angle (rad). All types of nanoparticles obtained in this study had a large surface area, which is valuable for increasing their interaction with bacteria.

Growth of $P$. aeruginosa in the presence of the nanoparticles is shown in Figure 5. We examined the inhibitory effect over a period of 96 hours, which corresponds to the different phases of bacterial growth. Most importantly, in the exponential phase, bacterial growth was strongly inhibited by all types of SPION when compared with the corresponding BHI control $(P<0.05)$. The first period is the most important for bacterial growth, because bacteria populations are doubling in this time. We observed maximal inhibition of bacteria growth by the uncoated and gold-functionalized

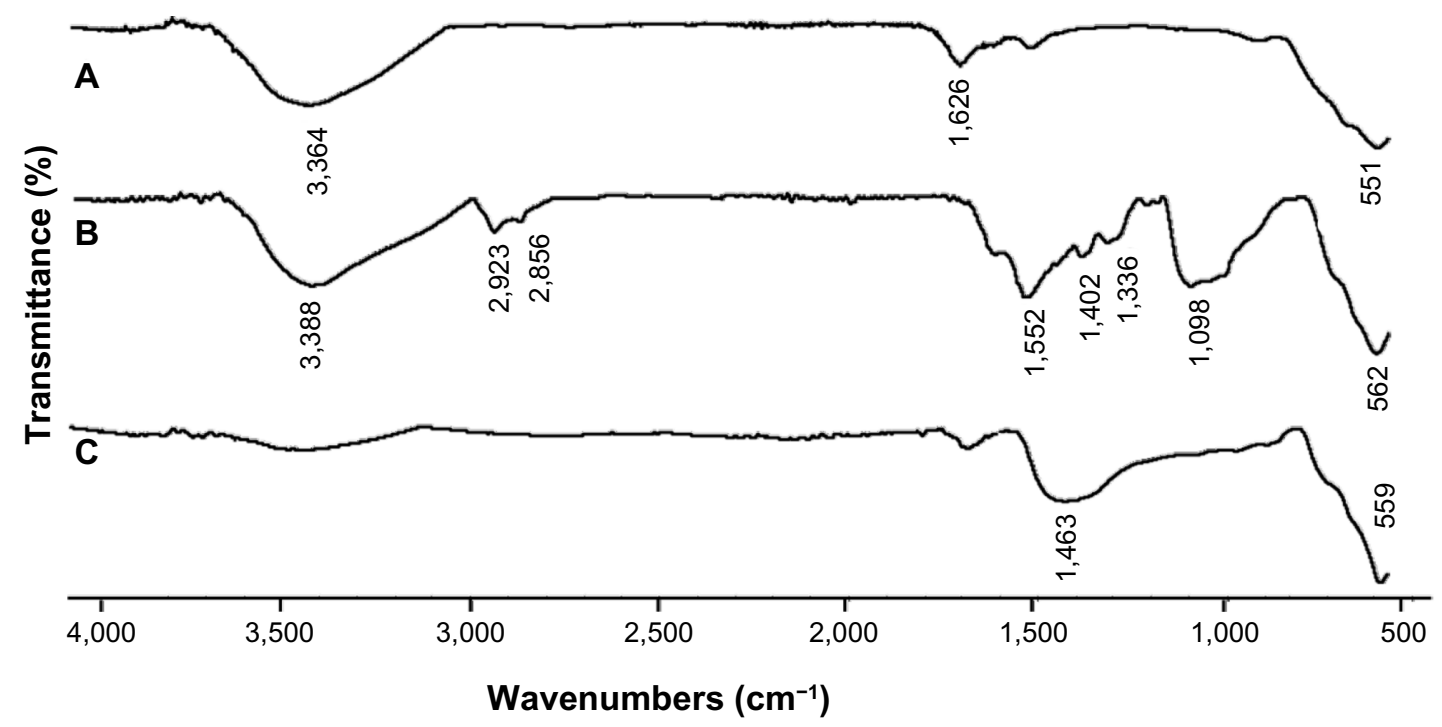

Figure I Fourier transform infrared spectra of $(\mathbf{A})$ uncoated nanoparticles $\left(\mathrm{Fe}_{3} \mathrm{O}_{4}\right),(\mathbf{B})$ aminosilane-functionalized nanoparticles $\left(\mathrm{Fe}_{3} \mathrm{O}_{4} @ \mathrm{NH}_{2}\right)$, and $(\mathbf{C})$ gold-functionalized nanoparticles $\left(\mathrm{Fe}_{3} \mathrm{O}_{4} @ \mathrm{Au}\right)$. 
A
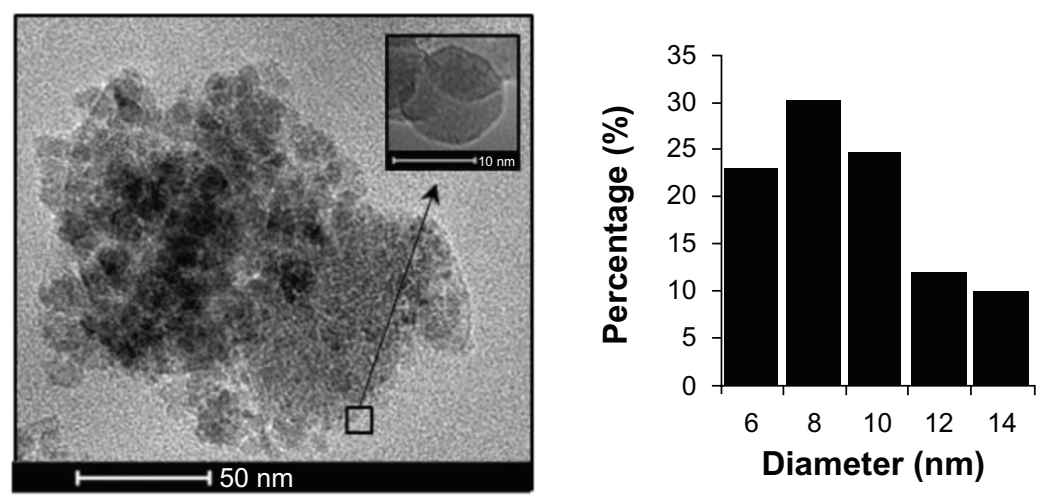

B
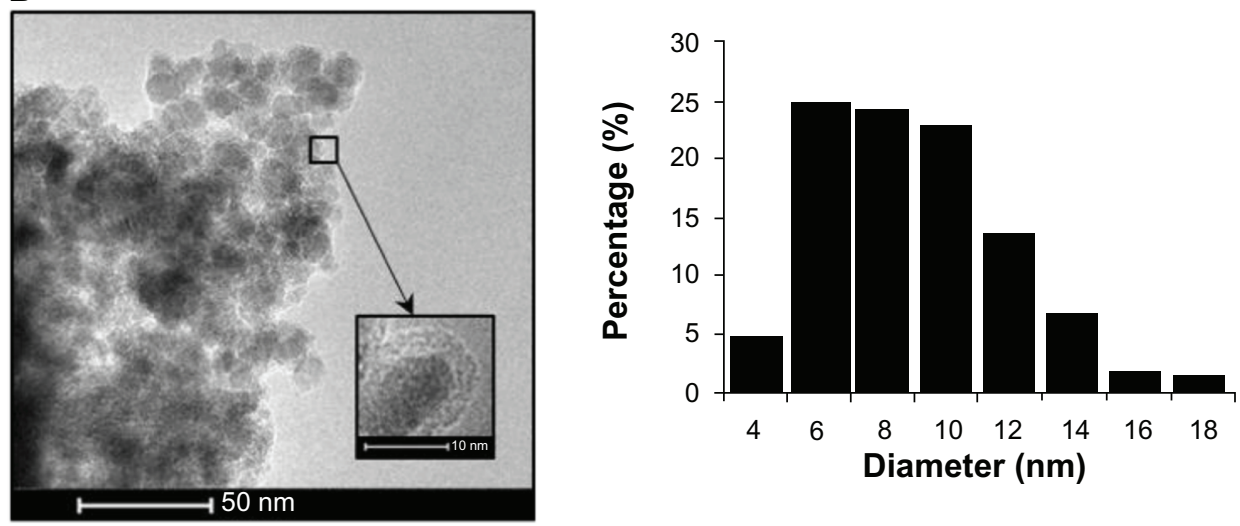

C
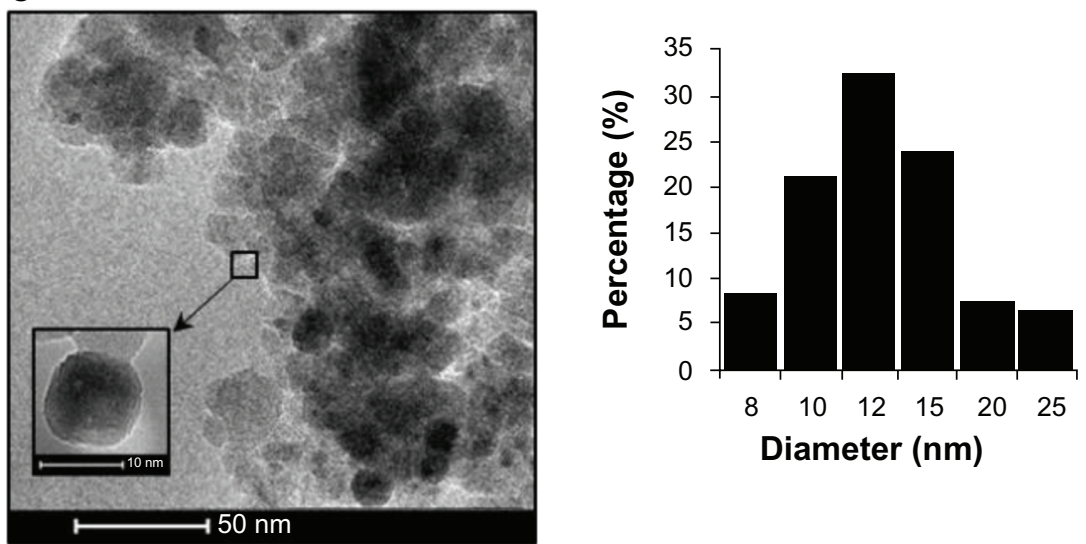

Figure 2 Transmission electron microscopic images of $(\mathbf{A})$ uncoated $\mathrm{Fe}_{3} \mathrm{O}_{4},(\mathbf{B})$ aminosilane-functionalized nanoparticles $\left(\mathrm{Fe}_{3} \mathrm{O}_{4} @ \mathrm{NH}_{2}\right)$, and $(\mathbf{C})$ gold-functionalized nanoparticles $\left(\mathrm{Fe}_{3} \mathrm{O}_{4} @ \mathrm{Au}\right)$, and histograms of the size distribution of the particle diameters.

Note: Gold-functionalized and aminosilane-functionalized nanoparticles had an iron oxide core of $8 \pm 2 \mathrm{~nm}$.

Table I EDAX/TEM analysis of elements in the $\mathrm{Fe}_{3} \mathrm{O}_{4} @ \mathrm{NH}_{2}$ nanoparticles

\begin{tabular}{lll}
\hline Element & Weight (\%) & Atomic (\%) \\
\hline $\mathrm{Fe}$ & 39.78 & 13.78 \\
$\mathrm{C}$ & $35.5 \mathrm{I}$ & 57.22 \\
$\mathrm{O}$ & 22.96 & 27.78 \\
$\mathrm{Si}$ & 1.73 & 1.19 \\
\hline
\end{tabular}

Note: Atomic value is obtained from EDAX analysis and estimate the elementary composition of the nanoparticles.

Abbreviations: Fe, iron; C, carbon; O, oxygen; Si, silicon; Au, gold; EDAX, energy dispersive spectrometry; TEM, transmission electron microscopy.
Table 2 EDAX/TEM analysis of elements in the $\mathrm{Fe}_{3} \mathrm{O}_{4} @ \mathrm{Au}$ nanoparticles

\begin{tabular}{lll}
\hline Element & Weight (\%) & Atomic (\%) \\
\hline Fe & 44.99 & 18.23 \\
$\mathrm{C}$ & 25.13 & 47.37 \\
$\mathrm{O}$ & 23.82 & 33.69 \\
$\mathrm{Au}$ & 6.05 & 0.69 \\
\hline
\end{tabular}

Note: Atomic value is obtained from EDAX analysis and estimate the elementary composition of the nanoparticles.

Abbreviations: Fe, iron; C, carbon; O, oxygen; Si, silicon; Au, gold; EDAX, energy dispersive spectrometry; TEM, transmission electron microscopy. 

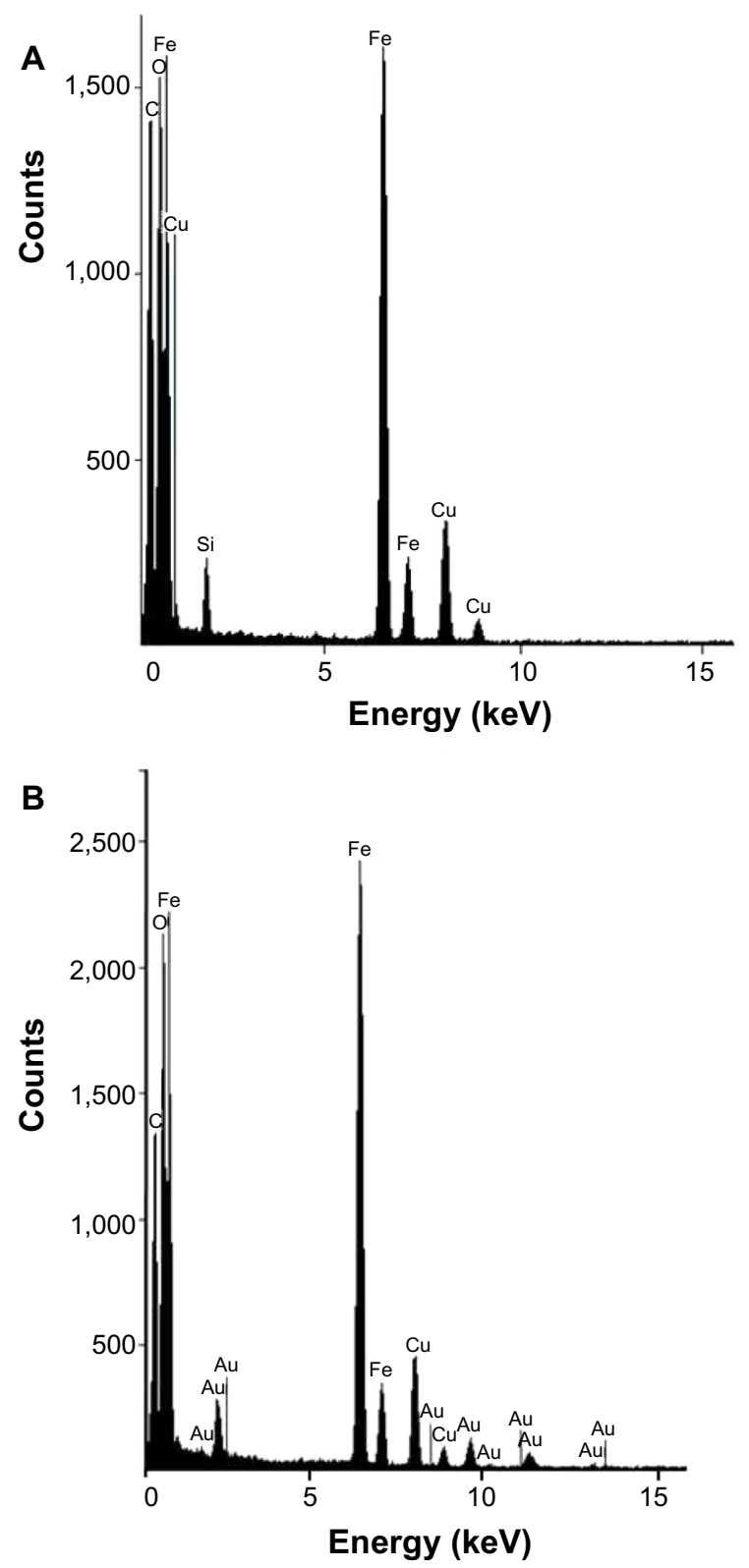

Figure 3 Energy-dispersive $X$-ray spectra of $\mathrm{Fe}_{3} \mathrm{O}_{4}$ nanoparticles functionalized with aminosilane $\left(\mathrm{Fe}_{3} \mathrm{O}_{4} @ \mathrm{NH}_{2}\right)(\mathbf{A})$ and with gold $\left(\mathrm{Fe}_{3} \mathrm{O}_{4} @ \mathrm{Au}\right)(\mathbf{B})$.

nanoparticles during the stationary phase. After 48 hours of treatment with gold-functionalized SPIONs, the number of bacteria decreased $10^{7}$ times compared with the control. In addition, an interesting inhibitory effect was observed with the nonfunctionalized nanoparticles, whereby we observed a 100-fold depletion of bacterial numbers when compared with the control. The amine-functionalized SPIONs resulted in a 10 -fold decrease that was not statistically significant. During the death phase, only gold-coated SPIONs had a statistically significant inhibitory effect. We suggest that these particles exert a strong bacteriostatic effect. This long-term effect, which was observed at 96 hours, clearly indicates that gold-

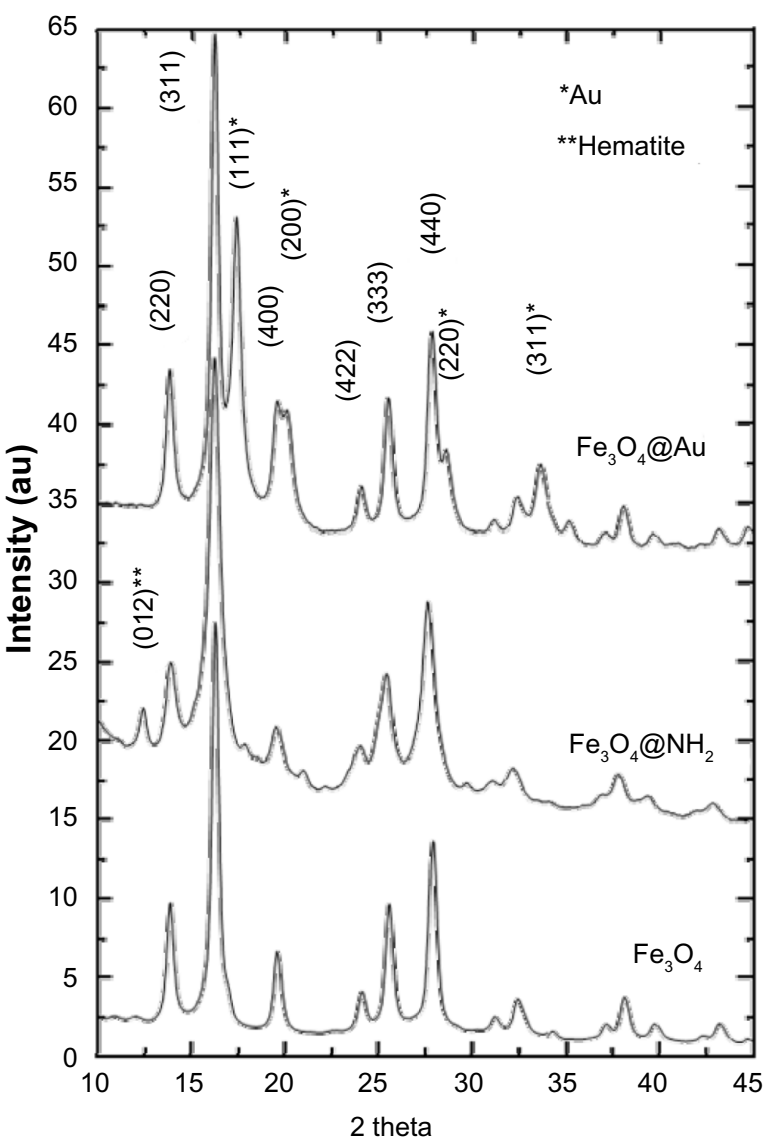

Figure $4 \mathrm{X}$-ray diffraction patterns of $\mathrm{Fe}_{3} \mathrm{O}_{4}$ nanoparticles functionalized with aminosilane $\left(\mathrm{Fe}_{3} \mathrm{O}_{4} @ \mathrm{NH}_{2}\right)$ or gold $\left(\mathrm{Fe}_{3} \mathrm{O}_{4} @ \mathrm{Au}\right)$.

Abbreviation: au, arbitrary units.

functionalized nanoparticles have a strong impact on the cell metabolism process.

Evaluation of the risk associated with exposure to nanoparticles is important not only for bacteria but also for normal healthy cells before nanoparticles can be used as medical tools. Previously, using a CRL-1747 human skin fibroblast cell line, we demonstrated an absence of toxicity for $\mathrm{Fe}_{3} \mathrm{O}_{4} @ \mathrm{Au}$ used at the same concentrations as in our present study. ${ }^{25}$ These nanoparticles were fully compatible with fibroblasts (Figure 6). Our data therefore show a dual effect of gold-functionalized SPIONs, ie, no toxicity to human skin fibroblasts and a toxic effect on $P$. aeruginosa. The observed difference in effect of these nanoparticles, ie, their toxicity against bacteria and a lack of impact on healthy human cells, provides an opportunity for their future investigation in biomedical applications.

On the basis of these data, we hypothesize that the gold present on the SPION surface interacts with bacterial proteins via their strong affinity for disulfide bonds, which can affect metabolism as well as the redox systems of bacterial cells. To confirm this mechanism, we performed a microscopy analysis 


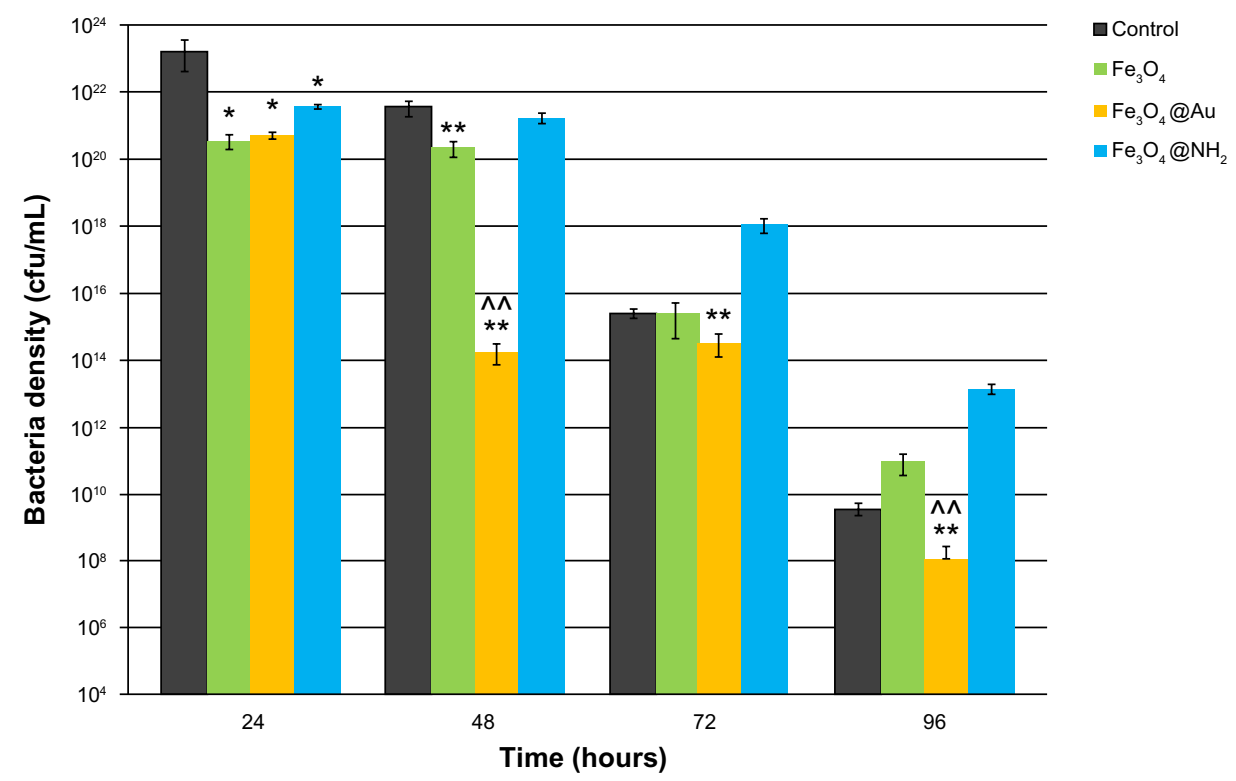

Figure 5 Effect of different types of superparamagnetic iron nanoparticles on growth of Pseudomonas aeruginosa for selected time periods of 24, 48,72 , and 96 hours. Notes: The strongest inhibitory effect on growth of $P$. aeruginosa was observed for superparamagnetic iron nanoparticles coated by a gold shell (Fe $\mathrm{O}_{4} @ \mathrm{Au}_{\mathrm{u}}$ and for uncoated superparamagnetic iron nanoparticles $\left(\mathrm{Fe}_{3} \mathrm{O}_{4}\right)$. The results are shown as the mean \pm standard deviation for $\mathrm{n}=3$. $* P \leq 0.05$ and $* * P \leq 0.0 \mathrm{I}$ indicate statistical significance versus control; $\wedge \wedge P \leq 0.0$ I indicates statistical significance versus nonfunctionalized superparamagnetic iron oxide nanoparticles.

Abbreviations: cfu, colony forming units; $\mathrm{Fe}_{3} \mathrm{O}_{4} @ \mathrm{NH}_{2}$, aminosilane functionalized nanoparticles.

of the particles at a concentration of $2.5 \mathrm{mg} / \mathrm{mL}$ at the 24 -hour time point (Figure 7). The results suggested that $\mathrm{Fe}_{3} \mathrm{O}_{4} @ \mathrm{Au}$ attach to the bacterial membrane and disturb its integrity. Damage to the bacterial cell wall via electrostatic interactions contributes to increased membrane permeability, perforation of the plasma membrane, and disruption of cell metabolism. We observed marked changes in the morphological features of the bacteria, including their size and shape.

We also hypothesize that gold-coated SPIONs target a structural protein, potentially Protein F, which maintains

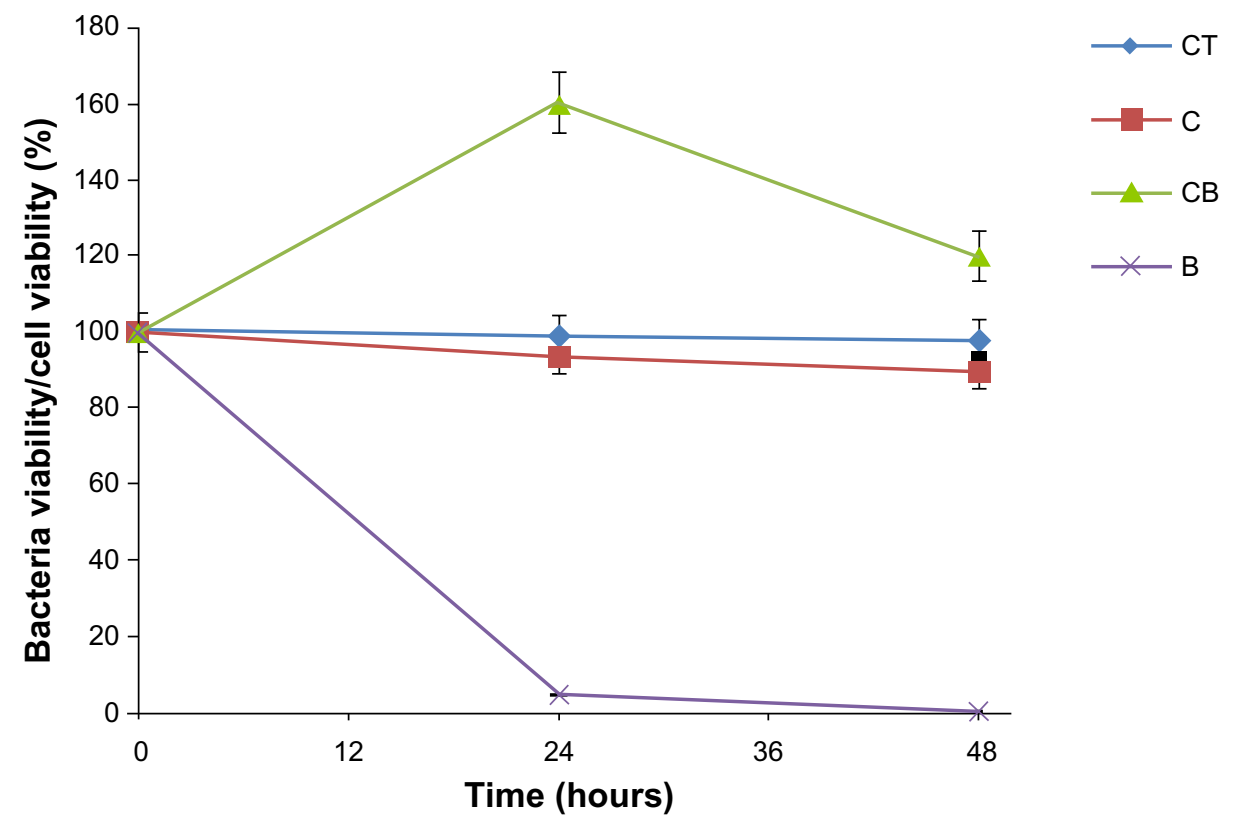

Figure 6 Lack of cytotoxicity in CRL-1747 human skin fibroblast cells and bactericidal effect after treatment with Fe $\mathrm{O}_{4}$ nanoparticles functionalized with gold (Fe $\mathrm{O}_{4} @ \mathrm{Au}$ ). The results are shown as the mean \pm standard deviation for $n=3$.

Abbreviations: $\mathrm{CT}$, control cells; $\mathrm{C}$, cells after treatment with $\mathrm{Fe}_{3} \mathrm{O}_{4} @ \mathrm{Au} ; \mathrm{CB}$, control bacterial cells; $\mathrm{B}$, bacterial cells after treatment with Fe $\mathrm{O}_{4} @ \mathrm{Au}$. 


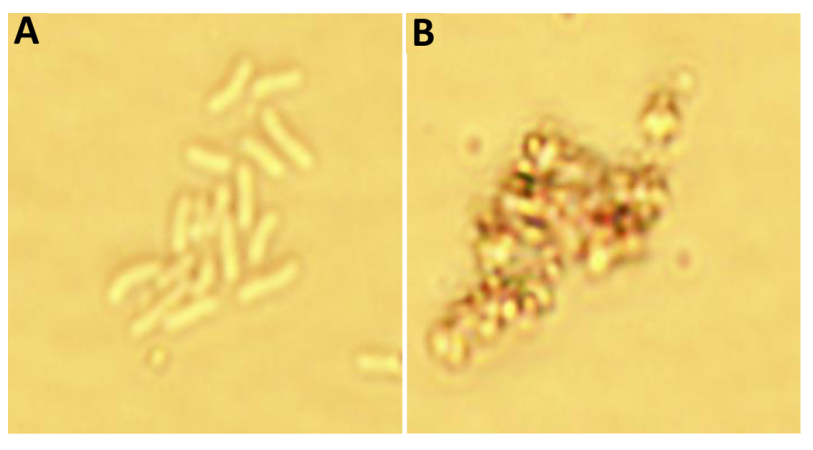

Figure 7 Toxicity of gold-functionalized nanoparticles $\left(\mathrm{Fe}_{3} \mathrm{O}_{4} @ \mathrm{Au}\right)$ against bacteria cells. (A) Control P. aeruginosa cells; (B) P. aeruginosa after treated goldfunctionalized nanoparticles ( $\left.\mathrm{Fe}_{3} \mathrm{O}_{4} @ \mathrm{Au}\right)$.

Notes: Microphotographs of Pseudomonas aeruginosa in the presence of gold coated magnetic nanoparticles. The images confirm the ability of nanoparticles to attach to the membrane of bacteria and disrupt the bacterial membrane and change the morphological features (shape and size) of bacteria cells. (magnification $\times 1000$ ).

the shape of the bacterial cell and controls transport of ions and molecules. This protein has been identified as an important factor contributing to the antimicrobial resistance of $P$. aeruginosa. ${ }^{26}$ Recent research suggests that unmodified SPIONs and their derivatives coated by a gold or gold-silver shell contribute to generation of reactive oxygen species and can interfere with electron transport during oxidation of nicotinamide adenine dinucleotide in bacteria. ${ }^{10,12,16,27,28}$ Another report proposes a Fenton reaction to explain bacterial cell death via damage of macromolecules including DNA, lipids, and protein. ${ }^{10}$ However, detailed metabolic analysis would be necessary to explain the toxic or biostatic effects of nanoparticles.

Many studies have shown that magnetic nanoparticles can be used as effective antimicrobial carriers in targeted therapy, although such methods may promote drug resistance in certain types of pathogens..$^{29,30}$ Recent studies have demonstrated an impact of various types of nanoparticles on inhibition of bacterial growth, but none have demonstrated long-term effects. ${ }^{10,11,31,32}$ Our study provides strong evidence that $\mathrm{Fe}_{3} \mathrm{O}_{4} @ \mathrm{Au}$ is capable of inhibiting growth of P. aeruginosa. It also shows that a shell around the magnetic core plays an important role in controlling the antimicrobial properties of nanomaterials. Our results suggest that SPIONs could be a valuable tool for developing new methods to treat and prevent bacterial infections.

\section{Conclusion}

The data presented here provide strong evidence that $\mathrm{Fe}_{3} \mathrm{O}_{4} @$ Au significantly reduce the growth of P. aeruginosa. The toxicity of $\mathrm{Fe}_{3} \mathrm{O}_{4} @$ Au against bacteria, as well as their compatibility with human healthy cells, could create a new approach towards fighting bacterial infection and warrants further investigation.

\section{Acknowledgments}

This work was financially supported by grants from the National Science Centre, Poland (UMO-2012/05/N/ NZ7/00534 to KN and UMO/2011/03/B/ST5/02691 to AZW). $\mathrm{KN}$ also acknowledges a doctoral scholarship from Polpharma Scientific Foundation. The equipment used for analysis in the Center of Synthesis and Analysis BioNanoTechno of University of Bialystok was funded by the European Union as part of the Operational Program Development of Eastern Poland 2007-2013 (project POPW.01.03.00-20-034/09-00). The authors are grateful to Ms Karolina H Markiewicz for assistance with the Fourier transform infrared analysis.

\section{Disclosure}

Data from the cytotoxicity assessment in human skin fibroblasts mentioned in this study were presented in abstract form at the 55th Congress of PTChem-SITPChem held on September 16-20 in Bialystok, Poland. Otherwise, the authors report no conflicts of interest in this work.

\section{References}

1. Mena KD, Gerba CP. Risk assessment of Pseudomonas aeruginosa in water. Rev Environ Contam Toxicol. 2009;201:71-115.

2. Hazlett L. Pseudomonas aeruginosa: my research passion. Future Microbiol. 2013;8:833-834.

3. Kelly NM, Bell A, Hancock RE. Surface characteristics of Pseudomonas aeruginosa grown in a chamber implant model in mice and rats. Infect Immun. 1989;57:344-350.

4. Bereket W, Hemalatha K, Getenet B, et al. Update on bacterial nosocomial infections. Eur Rev Med Pharmacol Sci. 2012;16: 1039-1044.

5. Ott E, Saathoff S, Graf K, Schwab F, Chaberny IF. The prevalence of nosocomial and community acquired infections in a university hospital: an observational study. Dtsch Arztebl Int. 2013;110:533-540.

6. Mulcahy LR, Isabella VM, Lewis K. Pseudomonas aeruginosa biofilms in disease. Microb Ecol. October 6, 2013. [Epub ahead of print.]

7. Lankford MG, Collins S, Youngberg L, Rooney DM, Warren JR, Noskin GA. Assessment of materials commonly utilized in health care: implications for bacterial survival and transmission. Am J Infect Control. 2006;34:258-263.

8. Niemirowicz K, Markiewicz KH, Wilczewska AZ, Car H. Magnetic nanoparticles as new diagnostic tools in medicine. Adv Med Sci. 2012;57:196-207.

9. Taylor E, Webster TJ. Reducing infections through nanotechnology and nanoparticles. Int J Nanomedicine. 2011;6:1463-1473.

10. Leuba KD, Durmus NG, Taylor EN, Webster TJ. Short communication: carboxylate functionalized superparamagnetic iron oxide nanoparticles (SPION) for the reduction of $S$. aureus growth post biofilm formation. Int J Nanomedicine. 2013;8:731-736.

11. Wang Q, Perez JM, Webster TJ. Inhibited growth of Pseudomonas aeruginosa by dextran- and polyacrylic acid-coated ceria nanoparticles. Int J Nanomedicine. 2013;8:3395-3399.

12. Hajipour MJ, Fromm KM, Ashkarran AA, et al. Antibacterial properties of nanoparticles. Trends Biotechnol. 2012;30:499-511. 
13. Ashkarran AA, Ghavami M, Aghaverdi H, Stroeve P, Mahmoudi M. Bacterial effects and protein corona evaluations: crucial ignored factors in the prediction of bio-efficacy of various forms of silver nanoparticles. Chem Res Toxicol. 2012;25:1231-1242.

14. Daima HK, Selvakannan PR, Shukla R, Bhargava SK, Bansal V. Finetuning the antimicrobial profile of biocompatible gold nanoparticles by sequential surface functionalization using polyoxometalates and lysine. PLoS One. 2013;8:e79676.

15. Daima HK, Selvakannan PR, Kandjani AE, Shukla R, Bhargava SK, Bansal V. Synergistic influence of polyoxometalate surface corona towards enhancing the antibacterial performance of tyrosine-capped Ag nanoparticles. Nanoscale. 2014;6:758-765.

16. Bajpai AK, Gupta R. Magnetically mediated release of ciprofloxacin from polyvinyl alcohol based superparamagnetic nanocomposites. J Mater Sci Mater Med. 2011;22:357-369.

17. Mahmoudi M, Serpooshan V. Silver-coated engineered magnetic nanoparticles are promising for the success in the fight against antibacterial resistance threat. ACS Nano. 2012;6:2656-2664.

18. Park H, Park HJ, Kim JA, et al. Inactivation of Pseudomonas aeruginosa PA01 biofilms by hyperthermia using superparamagnetic nanoparticles. J Microbiol Methods. 2011;84:41-45.

19. Massart R. Preparation of aqueous magnetic liquids in alkaline and acidic media. IEEE Trans Magn. 1981;17:1247-1248.

20. Kah JCY, Phonthammachai N, Wan RCY, et al. Synthesis of gold nanoshells based on the deposition-precipitation process. Gold Bulletin. 2008;41:23-36.

21. Mahadevan S, Gnanaprakash G, Philip J, Rao BPC, Jayakumar T. $\mathrm{X}$-ray diffraction-based characterization of magnetite nanoparticles in presence of goethite and correlation with magnetic properties. Physica E. 2007;39:20-25.

22. Souza FL, Lopes KP, Nascente PAP, Leite ER. Nanostructured hematite thin films produced by spin-coating deposition solution: application in water splitting. Sol Energy Mater Sol C. 2009;93:362-368.
23. Robinson I, Tung le D, Maenosono S, Wälti C, Thanh NT. Synthesis of core-shell gold coated magnetic nanoparticles and their interaction with thiolated DNA. Nanoscale. 2010;2:2624-2630.

24. El Ghandoor H, Zidan HM, Mostafa Khalil MH, Ismail MIM. Synthesis and some physical properties of magnetite $\left(\mathrm{Fe}_{3} \mathrm{O}_{4}\right)$ nanoparticles. Int $J$ Electrochem Sci. 2012;7:5734-5745.

25. Niemirowicz K, Pawlus J, Rusak M, et al. [Effects of magnetic nanoparticles coated by gold or aminosilane shell at the cellular level]. Abstract presented at the 55th Congress of PTChem-SITPChem, September 16-20, Bialystok, Poland. Polish.

26. Woodruff WA, Hancock RE. Pseudomonas aeruginosa outer membrane protein F: structural role and relationship to the Escherichia coli OmpA protein. J Bacteriol. 1989;171:3304-3309.

27. Durmus NG, Taylor EN, Inci F, Kummer K, Tarquinio KM, Webster TJ. Fructose-enhanced reduction of bacterial growth on nanorough surfaces. Int J Nanomedicine. 2012;7:537-545.

28. Hetrick EM, Shin JH, Stasko NA, et al. Bactericidal efficacy of nitric oxide-releasing silica nanoparticles. ACS Nano. 2008;2:235-246.

29. Abdelghany SM, Quinn DJ, Ingram RJ, et al. Gentamicin-loaded nanoparticles show improved antimicrobial effects towards Pseudomonas aeruginosa infection. Int J Nanomedicine. 2012;7: 4053-4063.

30. Brown AN, Smith K, Samuels TA, Lu J, Obare SO, Scott ME. Nanoparticles functionalized with ampicillin destroy multipleantibiotic-resistant isolates of Pseudomonas aeruginosa and Enterobacter aerogenes and methicillin-resistant Staphylococcus aureus. Appl Environ Microbiol. 2012;78:2768-2774.

31. Tran N, Mir A, Mallik D, Sinha A, Nayar S, Webster TJ. Bactericidal effect of iron oxide nanoparticles on Staphylococcus aureus. Int J Nanomedicine. 2010;5:277-283.

32. Tran PA, Webster TJ. Selenium nanoparticles inhibit Staphylococcus aureus growth. Int J Nanomedicine. 2011;6:1553-1558.
International Journal of Nanomedicine

\section{Publish your work in this journal}

The International Journal of Nanomedicine is an international, peerreviewed journal focusing on the application of nanotechnology in diagnostics, therapeutics, and drug delivery systems throughout the biomedical field. This journal is indexed on PubMed Central, MedLine, CAS, SciSearch $\AA$, Current Contents ${ }^{\circledR} /$ Clinical Medicine,

\section{Dovepress}

Journal Citation Reports/Science Edition, EMBase, Scopus and the Elsevier Bibliographic databases. The manuscript management system is completely online and includes a very quick and fair peer-review system, which is all easy to use. Visit http://www.dovepress.com/ testimonials.php to read real quotes from published authors. 